\title{
IRREGULAR STEEL BUILDING STRUCTURES SUBJECTED TO BLAST LOADING
}

\author{
Amy COFFIELD, Hojjat ADELI \\ Department of Civil, Environmental, and Geodetic Engineering, The Ohio State University, \\ 470 Hitchcock Hall, 2070 Neil Avenue, Columbus, OH 43220 U.S.A.
}

Received 09 Jan 2015; accepted 30 Jun 2015

\begin{abstract}
In seismic design, structural irregularity has been found to have a significant influence on structural response. The impact of structural irregularity on the global response of steel frame structures subjected to blast loading has not been examined. In the paper, six seismically designed steel framed structures are considered: moment resisting frames (MRF), concentrically braced frames (CBF) and eccentrically braced frames (EBF) each with geometric irregularity in the plan and with a geometric irregularity in the elevation. The blast loads are assumed to be unconfined, free air burst detonated $15 \mathrm{ft}$ from one of the center columns. The structures are modeled and analyzed using the Applied Element Method, which allows the structure to be examined during and through structural failure. A plastic hinge analysis is performed as well as a comparative analysis observing roof deflection and acceleration to determine the effect of geometric irregularity under extreme blast loading conditions. Two different blast locations are examined. Conclusions of this research are a concentrically braced frame provides somewhat of a higher level of resistance to blast loading for irregular structures and geometric irregularity has an impact on the response of a structure subjected to blast loading.
\end{abstract}

Keywords: steel frame, blast loading, irregular frame, moment resisting frames, braced frame.

\section{Introduction}

In a recent paper, the authors studied the effectiveness of different framing systems for three seismically designed regular steel frame structures subjected to blast loading: a moment resisting frame (MRF), a concentrically braced frame $(\mathrm{CBF})$ and an eccentrically braced frame $(\mathrm{EBF})$ (Coffield, Adeli 2014). The blast loads are assumed to be unconfined, free air burst detonated $15 \mathrm{ft}$ from one of the center columns. The structures are modeled and analyzed using the Applied Element Method, which allows the structure to be evaluated during and through failure. Failure modes are investigated through a plastic hinge analysis and member failure comparison. Also, a global response analysis is observed through comparison of roof deflections and accelerations. A conclusion of that research was that braced frames provide a higher level of resistance to blast loading. Both the CBF and EBF had a smaller number of failed members and plastic hinges compared to the MRF. They also had smaller roof deflection and acceleration. The CBF yielded the fewest number of plastic hinges but the EBF had a slightly fewer number of failed members. In this paper that investigation is extended to multistory steel frames with plan and vertical irregularities.
Structural irregularity has a significant impact on the behavior of structures (Adeli, Chyou 1986; Adeli, Mabrouk 1986; Kim, Adeli 2005; Jiang, Adeli 2008; Nigdeli, Boduroğlu 2013; Young, Adeli 2014b; Gutierrez-Soto, Adeli 2014). Similar to seismic loads, blast loads are also dynamic loads where the mass, stiffness and configuration of the structure can have a major impact on the response. Very little research has been done on the global response of an irregular structure under blast loading conditions. Jayatilake et al. (2010) investigated nonlinear analysis of 20 story reinforced concrete structures with shear walls and varying vertical setbacks designed for dead, live and wind loading conditions subjected to blast loading. The parameters used in the investigation were peak deflection, acceleration, inter-story drift and bending moments at critical locations. They report that when the blast source is in front of the setback it causes less damage because less of the structure is in the proximity of the blast source.

To the best of the authors' knowledge, no research has been published on the response of irregular threedimensional (3D) steel structures under blast loading. In this paper, the behavior of six seismically designed irregular 3D steel structures subjected to blast loading is

Corresponding author: Hojjat Adeli

E-mail: adeli.1@osu.edu 
investigating using the Applied Element Method (AEM). The blast loads are assumed to be unconfined, free air burst detonated $15 \mathrm{ft}$ from one of the center columns. Description of the AEM as well as a description of the blast loading are presented in Coffield and Adeli (2014). Two different types of irregularity are considered per ASCE 7-10 code (ASCE 2010):

1. Horizontal irregularity: exists when both plan projections of the structure beyond a reentrant corner are greater than $15 \%$ of the plan dimension of the structure in the given direction.

2. Vertical geometric irregularity: exists when the horizontal dimension of the seismic force resisting system in any story is more than $130 \%$ of any adjacent story.

The structures are all subjected to a blast load of 2 kips.

\section{Modelling}

\subsection{Building design}

Six 10-story, 5-bay steel structures designed according to AISC (LRFD) (AISC 2010) and ASCE 7-10 (ASCE 2010) are investigated in this paper: two MRFs, two CBFs, and two EBFs each with one having a vertical irregularity and another with a horizontal reentrant corner irregularity. These structures correspond to the three regular 10-story MRF, CBF, and EBF structures presented in Coffield and Adeli (2014) and are designed following the same guidelines.

The three horizontally irregular structures are presented in Figure 1. The horizontal reentrant corner irregularity has a $50 \mathrm{ft}$ by $50 \mathrm{ft}$ cutout in the plan view of each type of structure. The three vertically irregular structures are presented in Figure 2. The vertical irregularity consists of a $30 \mathrm{ft}$ by $50 \mathrm{ft}$ cutout on one side of the structure.

Designs for the EBF and CBF structures were obtained from previous research done by Young and Adeli (2014a) on the fundamental period of the structure. The MRF was designed in this research utilizing STAAD Pro V8i as the design software. Member data (all W shapes) for the structures are given in Tables 1 to 3 for the horizontally irregular structures and Tables 4 to 6 for the vertically irregular structures. All other design assumptions including material properties are the same as those for the corresponding regular structures presented in Coffield and Adeli (2014).

\subsection{Applying the AEM}

The Applied Element Method is used to model and analyze the six geometrically irregular structures. A finer mesh is used for members in the first four stories that are closer to the blast source. A large number of elements, approximately 36,500 for the horizontally irregular structures and 38,000 for the vertically irregular structures are used for each structure. The first through fourth story slabs containing a horizontal irregularity have 2100 ele-

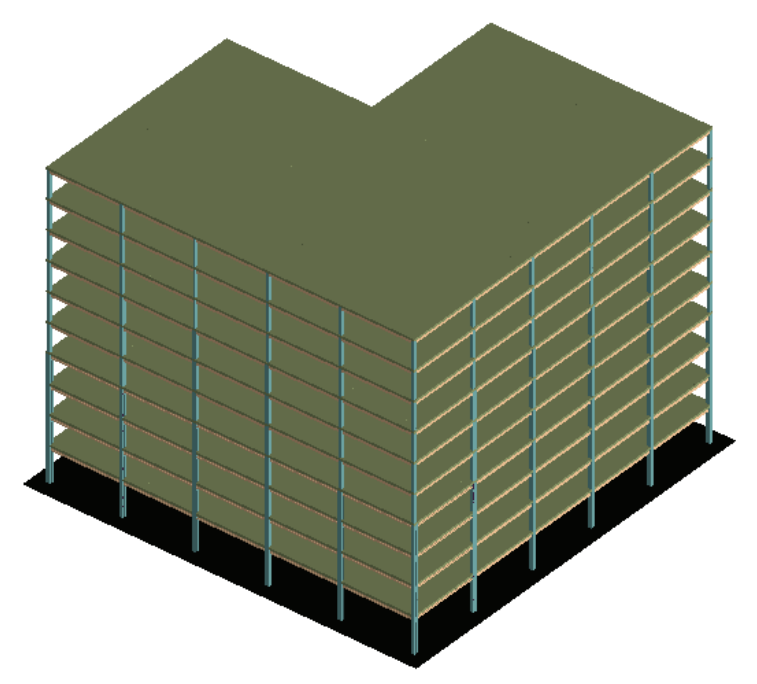

(A) MRF

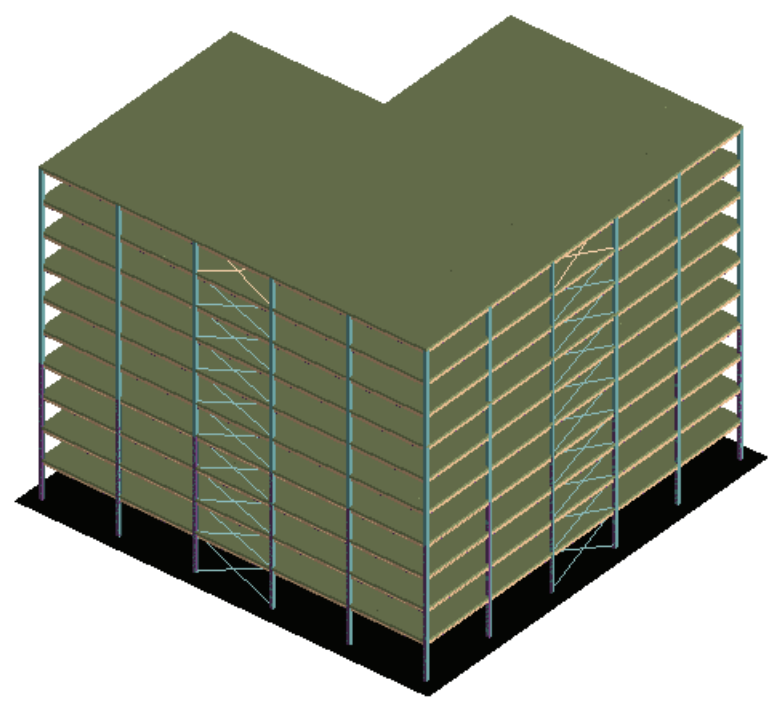

(B) $\mathrm{CBF}$

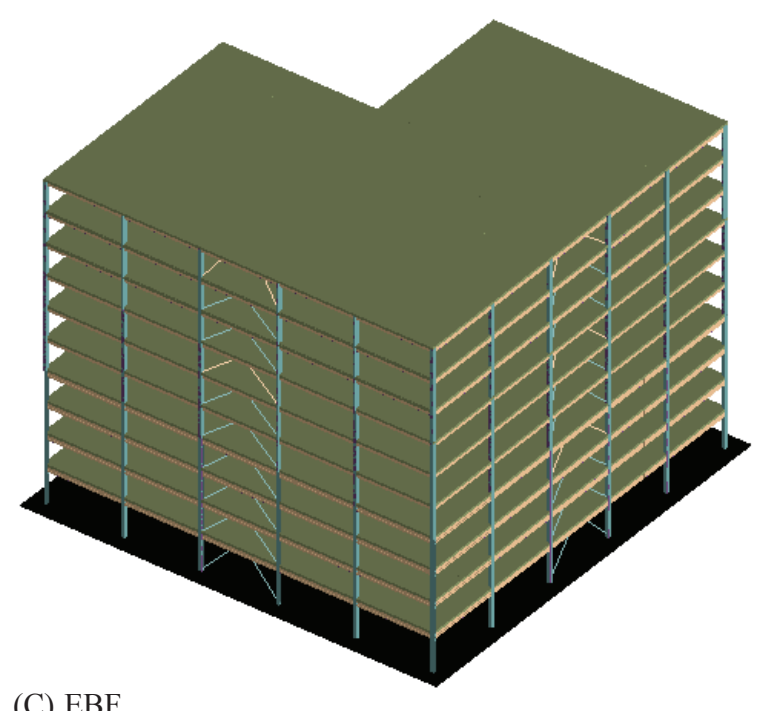

(C) $\mathrm{EBF}$

Fig. 1. Horizontally irregular MRF, CBF, and EBF 


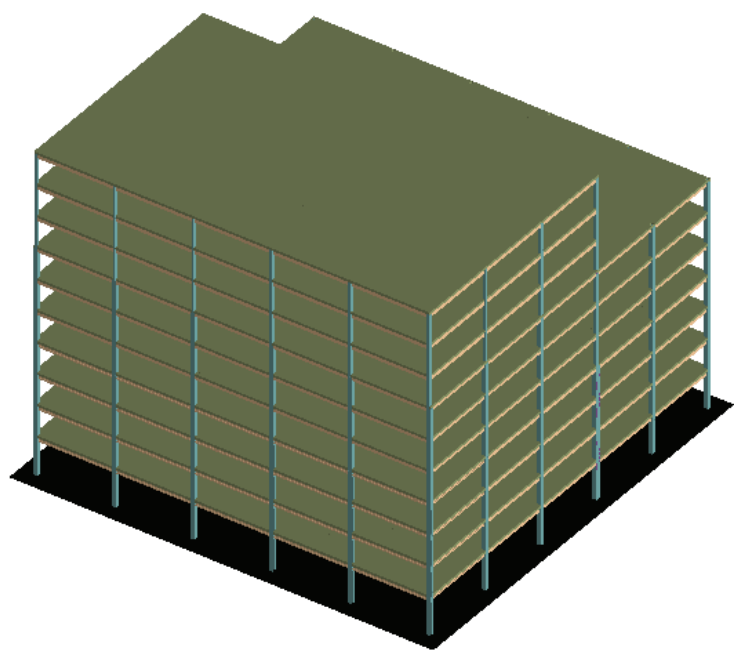

(A) MRF

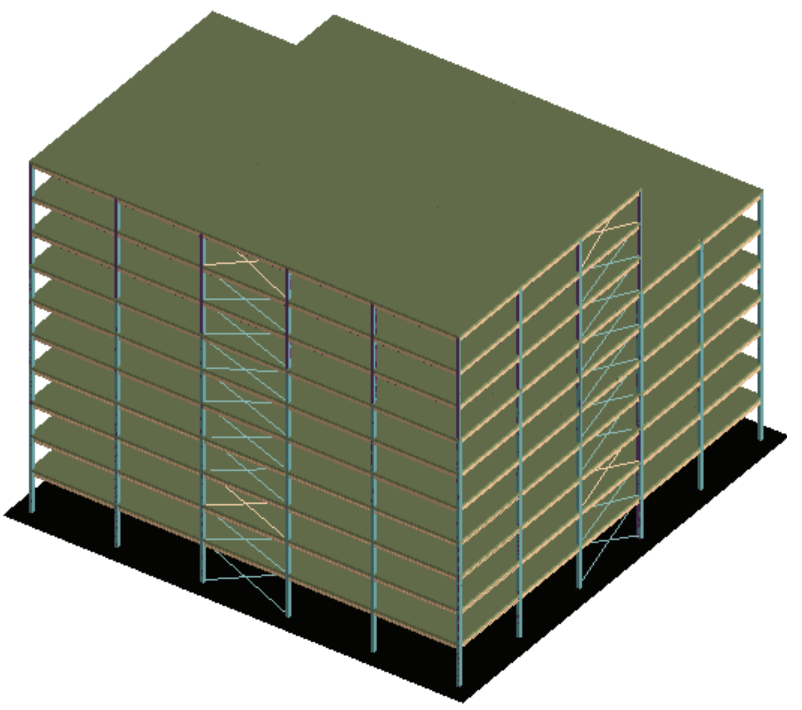

(B) $\mathrm{CBF}$

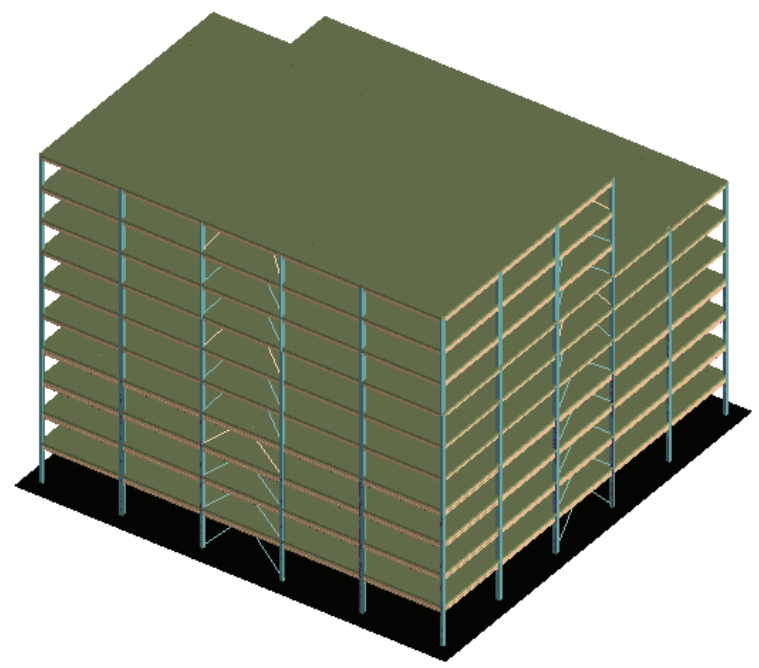

(C) $\mathrm{EBF}$

Fig. 2. Vertically irregular MRF, CBF, and EBF
Table 1. Member data for horizontally irregular - Moment Resisting Frame (MRF)

\begin{tabular}{c|c|c|c}
\hline Story (i) & $\begin{array}{c}\text { Column } \\
\text { section }\end{array}$ & $\begin{array}{c}\text { Beam section }- \\
\text { interior }\end{array}$ & $\begin{array}{c}\text { Beam section - } \\
\text { perimeter }\end{array}$ \\
\hline 10 & $\mathrm{~W} 14 \times 61$ & $\mathrm{~W} 14 \times 68$ & $\mathrm{~W} 14 \times 48$ \\
9 & $\mathrm{~W} 14 \times 61$ & $\mathrm{~W} 14 \times 68$ & $\mathrm{~W} 14 \times 48$ \\
8 & $\mathrm{~W} 14 \times 61$ & $\mathrm{~W} 14 \times 68$ & $\mathrm{~W} 14 \times 48$ \\
7 & $\mathrm{~W} 14 \times 99$ & $\mathrm{~W} 14 \times 48$ & $\mathrm{~W} 14 \times 48$ \\
6 & $\mathrm{~W} 14 \times 99$ & $\mathrm{~W} 14 \times 48$ & $\mathrm{~W} 14 \times 48$ \\
5 & $\mathrm{~W} 14 \times 99$ & $\mathrm{~W} 14 \times 48$ & $\mathrm{~W} 14 \times 48$ \\
4 & $\mathrm{~W} 14 \times 193$ & $\mathrm{~W} 16 \times 57$ & $\mathrm{~W} 16 \times 45$ \\
3 & $\mathrm{~W} 14 \times 193$ & $\mathrm{~W} 16 \times 57$ & $\mathrm{~W} 16 \times 45$ \\
2 & $\mathrm{~W} 14 \times 193$ & $\mathrm{~W} 16 \times 57$ & $\mathrm{~W} 16 \times 45$ \\
1 & $\mathrm{~W} 14 \times 193$ & $\mathrm{~W} 16 \times 57$ & $\mathrm{~W} 16 \times 45$ \\
\hline
\end{tabular}

Table 2. Member data for horizontally irregular -

Concentrically Braced Frame (CBF) (Young, Adeli 2014a, 2014b)

\begin{tabular}{c|c|c|c|c}
\hline Story (i) & $\begin{array}{c}\text { Column } \\
\text { section }\end{array}$ & $\begin{array}{c}\text { Beam }- \\
\text { interior }\end{array}$ & $\begin{array}{c}\text { Beam }- \\
\text { perimeter }\end{array}$ & $\begin{array}{c}\text { Bracing } \\
\text { section }\end{array}$ \\
\hline 10 & $\mathrm{~W} 12 \times 53$ & $\mathrm{~W} 14 \times 48$ & $\mathrm{~W} 14 \times 38$ & $\mathrm{~W} 14 \times 68$ \\
9 & $\mathrm{~W} 12 \times 53$ & $\mathrm{~W} 14 \times 48$ & $\mathrm{~W} 14 \times 38$ & $\mathrm{~W} 14 \times 68$ \\
8 & $\mathrm{~W} 12 \times 53$ & $\mathrm{~W} 14 \times 48$ & $\mathrm{~W} 14 \times 38$ & $\mathrm{~W} 14 \times 68$ \\
7 & $\mathrm{~W} 12 \times 106$ & $\mathrm{~W} 14 \times 43$ & $\mathrm{~W} 14 \times 34$ & $\mathrm{~W} 14 \times 68$ \\
6 & $\mathrm{~W} 12 \times 106$ & $\mathrm{~W} 14 \times 43$ & $\mathrm{~W} 14 \times 34$ & $\mathrm{~W} 14 \times 68$ \\
5 & $\mathrm{~W} 12 \times 106$ & $\mathrm{~W} 14 \times 43$ & $\mathrm{~W} 14 \times 34$ & $\mathrm{~W} 14 \times 68$ \\
4 & $\mathrm{~W} 12 \times 190$ & $\mathrm{~W} 14 \times 43$ & $\mathrm{~W} 14 \times 34$ & $\mathrm{~W} 12 \times 96$ \\
3 & $\mathrm{~W} 12 \times 190$ & $\mathrm{~W} 14 \times 43$ & $\mathrm{~W} 14 \times 34$ & $\mathrm{~W} 12 \times 96$ \\
2 & $\mathrm{~W} 12 \times 190$ & $\mathrm{~W} 14 \times 43$ & $\mathrm{~W} 14 \times 34$ & $\mathrm{~W} 12 \times 96$ \\
1 & $\mathrm{~W} 12 \mathrm{X} 190$ & $\mathrm{~W} 14 \mathrm{X} 43$ & $\mathrm{~W} 14 \mathrm{X} 34$ & $\mathrm{~W} 12 \mathrm{X} 96$ \\
\hline
\end{tabular}

Table 3. Member data horizontally irregular - Eccentrically Braced Frame (EBF) (Young, Adeli 2014a, 2014b)

\begin{tabular}{c|c|c|c|c}
\hline Story (i) & $\begin{array}{c}\text { Column } \\
\text { section }\end{array}$ & $\begin{array}{c}\text { Beam }- \\
\text { interior }\end{array}$ & $\begin{array}{c}\text { Beam }- \\
\text { perimeter }\end{array}$ & $\begin{array}{c}\text { Bracing } \\
\text { section }\end{array}$ \\
\hline 10 & $\mathrm{~W} 21 \times 62$ & $\mathrm{~W} 14 \times 48$ & $\mathrm{~W} 16 \times 40$ & $\mathrm{~W} 12 \times 30$ \\
9 & $\mathrm{~W} 21 \times 62$ & $\mathrm{~W} 14 \times 48$ & $\mathrm{~W} 16 \times 40$ & $\mathrm{~W} 12 \times 30$ \\
8 & $\mathrm{~W} 21 \times 62$ & $\mathrm{~W} 14 \times 48$ & $\mathrm{~W} 16 \times 40$ & $\mathrm{~W} 12 \times 30$ \\
7 & $\mathrm{~W} 16 \times 89$ & $\mathrm{~W} 14 \times 43$ & $\mathrm{~W} 12 \times 45$ & $\mathrm{~W} 12 \times 30$ \\
6 & $\mathrm{~W} 16 \times 89$ & $\mathrm{~W} 14 \times 43$ & $\mathrm{~W} 12 \times 45$ & $\mathrm{~W} 12 \times 30$ \\
5 & $\mathrm{~W} 16 \times 89$ & $\mathrm{~W} 14 \times 43$ & $\mathrm{~W} 12 \times 45$ & $\mathrm{~W} 12 \times 30$ \\
4 & $\mathrm{~W} 12 \times 136$ & $\mathrm{~W} 14 \times 43$ & $\mathrm{~W} 21 \times 68$ & $\mathrm{~W} 12 \times 40$ \\
3 & $\mathrm{~W} 12 \times 136$ & $\mathrm{~W} 14 \times 43$ & $\mathrm{~W} 21 \times 68$ & $\mathrm{~W} 12 \times 40$ \\
2 & $\mathrm{~W} 12 \times 136$ & $\mathrm{~W} 14 \times 43$ & $\mathrm{~W} 21 \times 68$ & $\mathrm{~W} 12 \times 40$ \\
1 & $\mathrm{~W} 12 \times 136$ & $\mathrm{~W} 14 \times 43$ & $\mathrm{~W} 21 \times 68$ & $\mathrm{~W} 12 \times 40$ \\
\hline
\end{tabular}


Table 4. Member data for vertically irregular - Moment Resisting Frame (MRF)

\begin{tabular}{c|c|c|c}
\hline Story (i) & $\begin{array}{c}\text { Column } \\
\text { section }\end{array}$ & $\begin{array}{c}\text { Beam section }- \\
\text { interior }\end{array}$ & $\begin{array}{c}\text { Beam section - } \\
\text { perimeter }\end{array}$ \\
\hline 10 & $\mathrm{~W} 14 \times 61$ & $\mathrm{~W} 14 \times 68$ & $\mathrm{~W} 14 \times 48$ \\
9 & $\mathrm{~W} 14 \times 61$ & $\mathrm{~W} 14 \times 68$ & $\mathrm{~W} 14 \times 48$ \\
8 & $\mathrm{~W} 14 \times 61$ & $\mathrm{~W} 14 \times 68$ & $\mathrm{~W} 14 \times 48$ \\
7 & $\mathrm{~W} 14 \times 99$ & $\mathrm{~W} 14 \times 48$ & $\mathrm{~W} 14 \times 48$ \\
6 & $\mathrm{~W} 14 \times 99$ & $\mathrm{~W} 14 \times 48$ & $\mathrm{~W} 14 \times 48$ \\
5 & $\mathrm{~W} 14 \times 99$ & $\mathrm{~W} 14 \times 48$ & $\mathrm{~W} 14 \times 48$ \\
4 & $\mathrm{~W} 14 \times 193$ & $\mathrm{~W} 16 \times 57$ & $\mathrm{~W} 16 \times 45$ \\
3 & $\mathrm{~W} 14 \times 193$ & $\mathrm{~W} 16 \times 57$ & $\mathrm{~W} 16 \times 45$ \\
2 & $\mathrm{~W} 14 \times 193$ & $\mathrm{~W} 16 \times 57$ & $\mathrm{~W} 16 \times 45$ \\
1 & $\mathrm{~W} 14 \times 193$ & $\mathrm{~W} 16 \times 57$ & $\mathrm{~W} 16 \times 45$ \\
\hline
\end{tabular}

Table 5. Member data for vertically irregular - Concentrically Braced Frame (CBF) (Young, Adeli 2014a, 2014b)

\begin{tabular}{c|c|c|c|c}
\hline Story (i) & $\begin{array}{c}\text { Column } \\
\text { section }\end{array}$ & $\begin{array}{c}\text { Beam }- \\
\text { interior }\end{array}$ & $\begin{array}{c}\text { Beam }- \\
\text { perimeter }\end{array}$ & $\begin{array}{c}\text { Bracing } \\
\text { section }\end{array}$ \\
\hline 10 & $\mathrm{~W} 12 \times 53$ & $\mathrm{~W} 14 \times 48$ & $\mathrm{~W} 14 \times 38$ & $\mathrm{~W} 12 \times 45$ \\
9 & $\mathrm{~W} 12 \times 53$ & $\mathrm{~W} 14 \times 48$ & $\mathrm{~W} 14 \times 38$ & $\mathrm{~W} 12 \times 45$ \\
8 & $\mathrm{~W} 12 \times 53$ & $\mathrm{~W} 14 \times 48$ & $\mathrm{~W} 14 \times 38$ & $\mathrm{~W} 12 \times 45$ \\
7 & $\mathrm{~W} 12 \times 96$ & $\mathrm{~W} 14 \times 43$ & $\mathrm{~W} 14 \times 34$ & $\mathrm{~W} 14 \times 68$ \\
6 & $\mathrm{~W} 12 \times 96$ & $\mathrm{~W} 14 \times 43$ & $\mathrm{~W} 14 \times 34$ & $\mathrm{~W} 14 \times 68$ \\
5 & $\mathrm{~W} 12 \times 96$ & $\mathrm{~W} 14 \times 43$ & $\mathrm{~W} 14 \times 34$ & $\mathrm{~W} 14 \times 68$ \\
4 & $\mathrm{~W} 12 \times 170$ & $\mathrm{~W} 12 \times 40$ & $\mathrm{~W} 14 \times 34$ & $\mathrm{~W} 12 \times 96$ \\
3 & $\mathrm{~W} 12 \times 170$ & $\mathrm{~W} 12 \times 40$ & $\mathrm{~W} 14 \times 34$ & $\mathrm{~W} 12 \times 96$ \\
2 & $\mathrm{~W} 12 \times 170$ & $\mathrm{~W} 12 \times 40$ & $\mathrm{~W} 14 \times 34$ & $\mathrm{~W} 12 \times 96$ \\
1 & $\mathrm{~W} 12 \times 170$ & $\mathrm{~W} 12 \times 40$ & $\mathrm{~W} 14 \times 34$ & $\mathrm{~W} 12 \times 96$ \\
\hline
\end{tabular}

Table 6. Member data for vertically irregular - Eccentrically Braced Frame (EBF) (Young, Adeli 2014a, 2014b)

\begin{tabular}{c|c|c|c|c}
\hline Story (i) & $\begin{array}{c}\text { Column } \\
\text { section }\end{array}$ & $\begin{array}{c}\text { Beam }- \\
\text { interior }\end{array}$ & $\begin{array}{c}\text { Beam - } \\
\text { perimeter }\end{array}$ & $\begin{array}{c}\text { Bracing } \\
\text { section }\end{array}$ \\
\hline 10 & $\mathrm{~W} 21 \times 62$ & $\mathrm{~W} 14 \times 53$ & $\mathrm{~W} 16 \times 40$ & $\mathrm{~W} 12 \times 30$ \\
9 & $\mathrm{~W} 21 \times 62$ & $\mathrm{~W} 14 \times 53$ & $\mathrm{~W} 16 \times 40$ & $\mathrm{~W} 12 \times 30$ \\
8 & $\mathrm{~W} 21 \times 62$ & $\mathrm{~W} 14 \times 53$ & $\mathrm{~W} 16 \times 40$ & $\mathrm{~W} 12 \times 30$ \\
7 & $\mathrm{~W} 12 \times 96$ & $\mathrm{~W} 14 \times 43$ & $\mathrm{~W} 12 \times 45$ & $\mathrm{~W} 14 \times 34$ \\
6 & $\mathrm{~W} 12 \times 96$ & $\mathrm{~W} 14 \times 43$ & $\mathrm{~W} 12 \times 45$ & $\mathrm{~W} 14 \times 34$ \\
5 & $\mathrm{~W} 12 \times 96$ & $\mathrm{~W} 14 \times 43$ & $\mathrm{~W} 12 \times 45$ & $\mathrm{~W} 14 \times 34$ \\
4 & $\mathrm{~W} 12 \times 152$ & $\mathrm{~W} 14 \times 43$ & $\mathrm{~W} 21 \times 68$ & $\mathrm{~W} 12 \times 40$ \\
3 & $\mathrm{~W} 12 \times 152$ & $\mathrm{~W} 14 \times 43$ & $\mathrm{~W} 21 \times 68$ & $\mathrm{~W} 12 \times 40$ \\
2 & $\mathrm{~W} 12 \times 152$ & $\mathrm{~W} 14 \times 43$ & $\mathrm{~W} 21 \times 68$ & $\mathrm{~W} 12 \times 40$ \\
1 & $\mathrm{~W} 12 \times 152$ & $\mathrm{~W} 14 \times 43$ & $\mathrm{~W} 21 \times 68$ & $\mathrm{~W} 12 \times 40$ \\
\hline
\end{tabular}

ments per slab and the top six stories have 525 elements per slab. The top three stories of the vertically irregular structure have a mesh size of 375 elements per slab. The same bilinear inelastic behavior presented in Coffield and Adeli (2014) is assumed to model the post-yield behavior of steel.

\subsection{Applying the blast loads}

Two blast locations are examined in this research. Figure 3 and Figure 4 show the two different locations of the blast source, one opposite of the setback or the reentrant corner (location 1) and the other on the side of the setback or the reentrant corner (location 2). Table 7 provides the blast parameters for the six structures.

\section{Results}

For the given blast locations and weight, all structures undergo damage with the loss of some beams and columns but none experiences a total or partial collapse. The structural elements closest to the blast sustained the most damage due to the higher blast pressures. A plastic hinge analysis for each example is performed. A member is considered failed whenever a) three plastic hinges form in the member or b) two elements in the mesh are separated. Global response is compared through time-histories of the roof deflection and acceleration.

Table 8 provides a summary of plastic hinge formations and member failure information for all six example structures subjected to a $2-\mathrm{K}$ blast load. All structures faced significant damage during the blast losing 5 or 6 first, second and third story beams and the column closest to the blast. In all examples plastic hinges begin to form almost instantaneously with the first forming in the column closest to the blast 0.003 seconds after detonation and continue to form as the blast wave spreads throughout the structure.

Figures 5 and 6 show the plastic hinge locations as well as the failed members indicated by a thick line for the three horizontally irregular structures for blast locations 1 and 2, respectively. Figures 7 and 8 show the plastic hinge locations as well as the failed members for the three vertically irregular structures for blast locations 1 and 2, respectively. Most plastic hinges were formed in the first, second and third story beams and columns closest to the blast. Anywhere between 2 to 4 plastic hinges were formed in the $4^{\text {th }}$ story beams. The plastic hinged formed very quickly with approximately two-thirds (56$68 \%$ ) of them forming within 0.01 second of detonation in all examples. The maximum roof deflection and acceleration in the direction of the blast for each example is given in Table 9.

\subsection{Comparison of the framing systems}

The number of plastic hinges and failed members and the roof deflection and acceleration are used to compare the three framing systems for each type of irregularity. All structures suffered a similar number of member failure, 
Table 7. Blast parameters

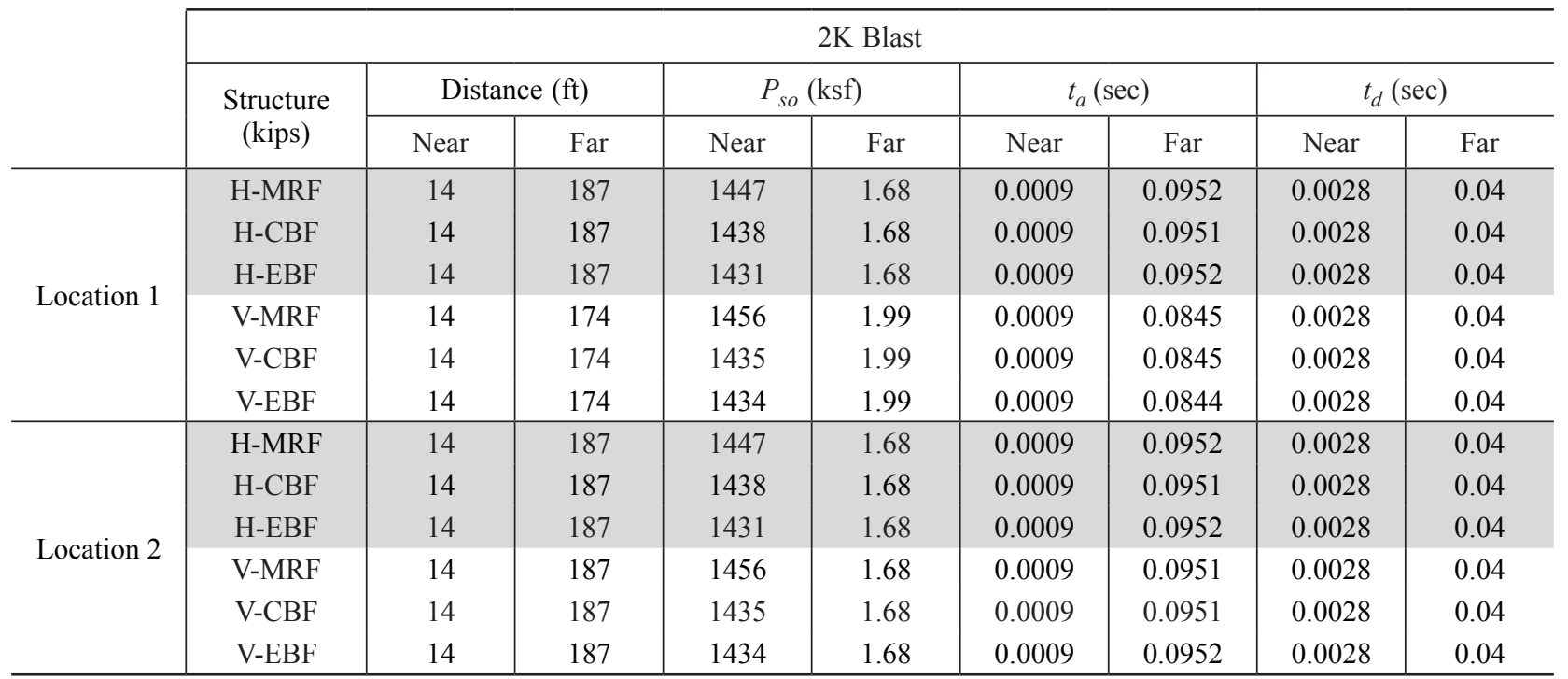
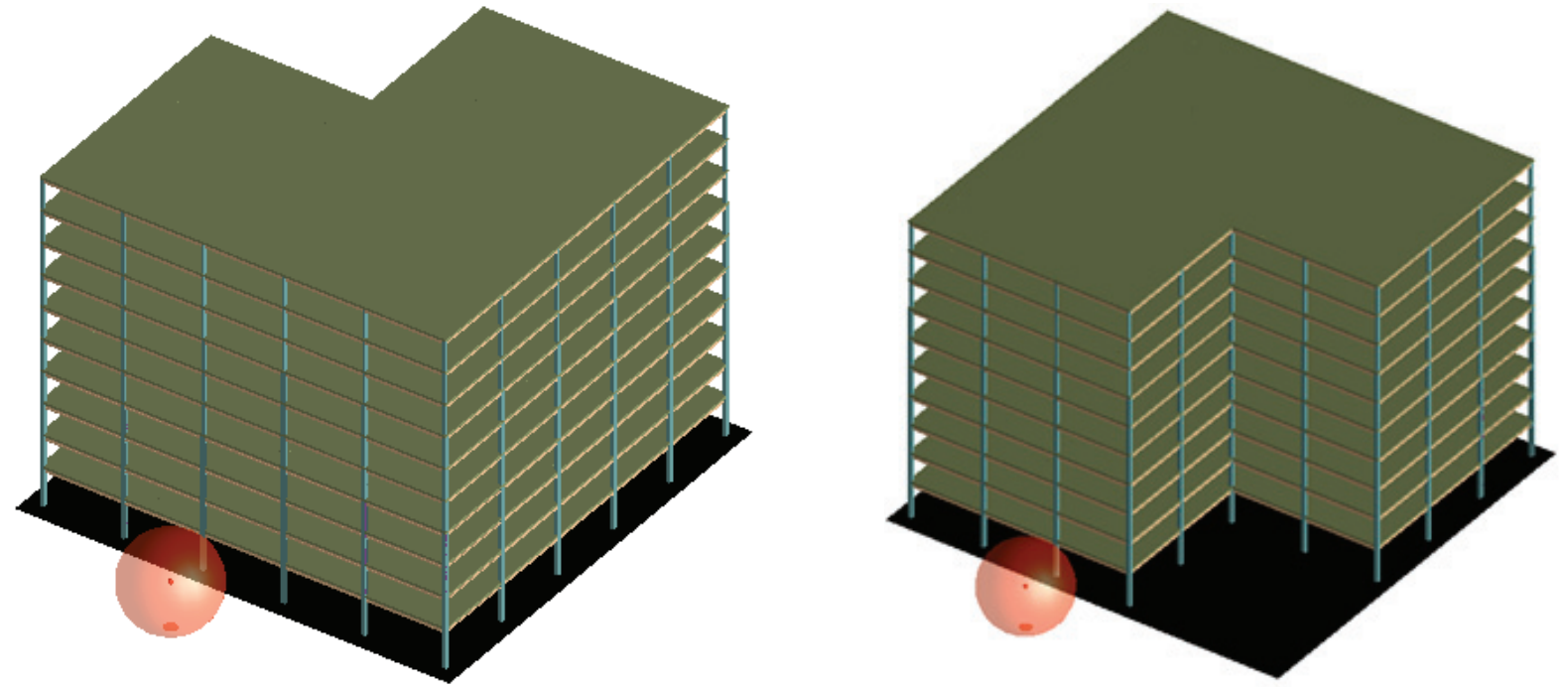

(a) Horizontally irregular structures
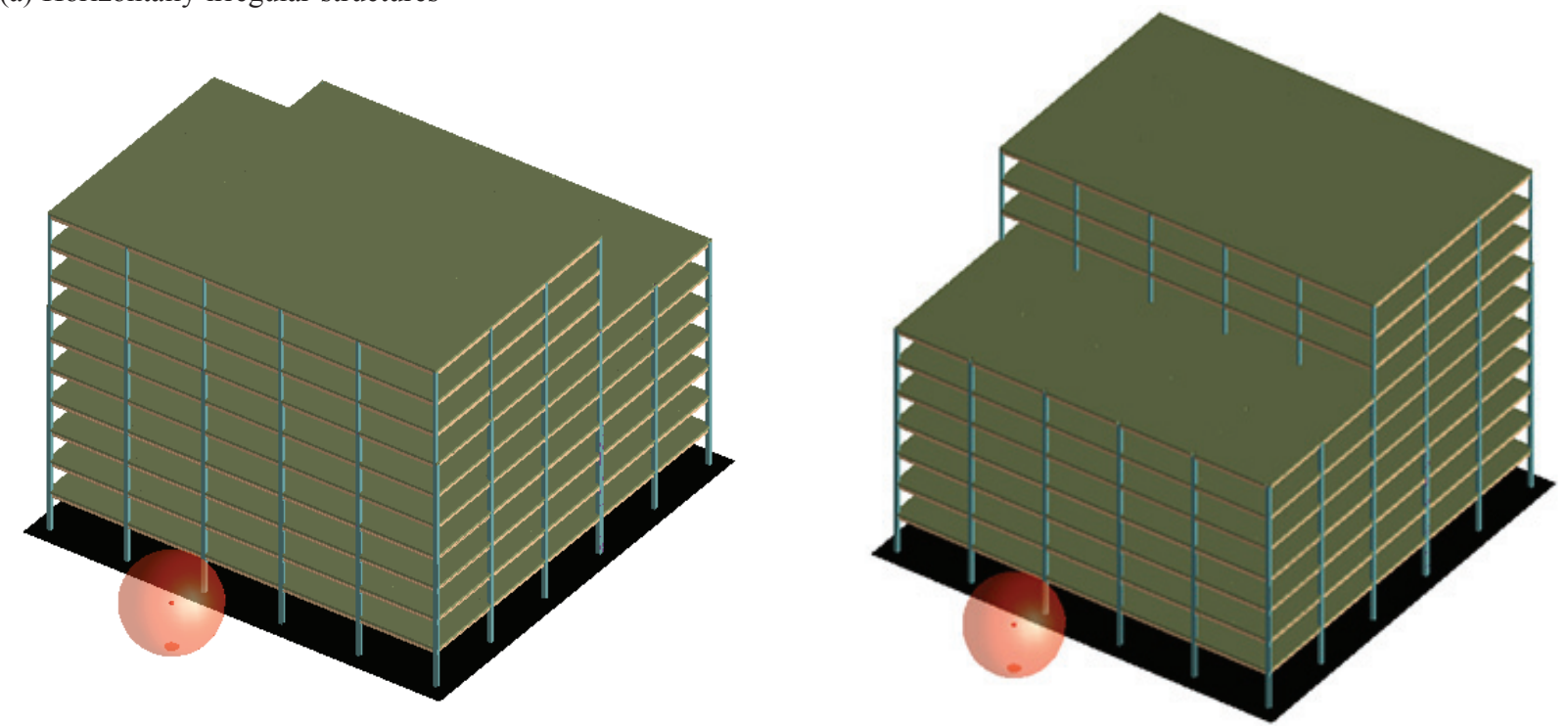

(b) Vertically irregular structures

Fig. 3. Blast location 1 - typical for MRF, CBF, EBF

Fig. 4. Blast location 2 - typical for MRF, CBF, EBF 


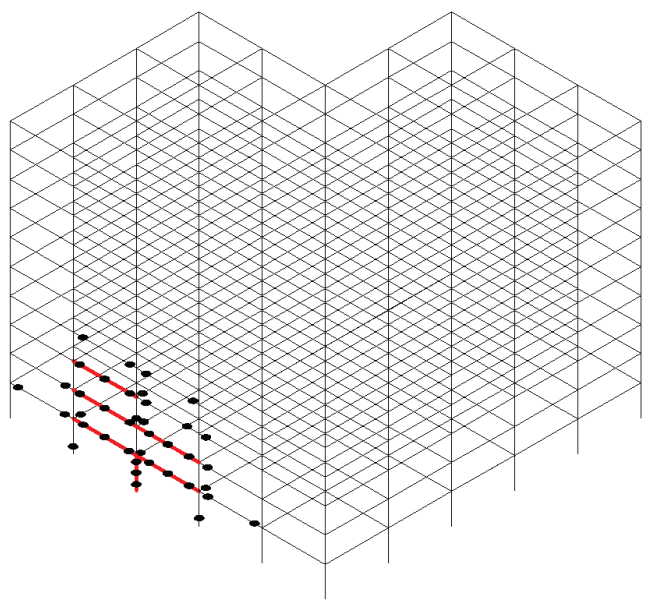

(a) H-MRF

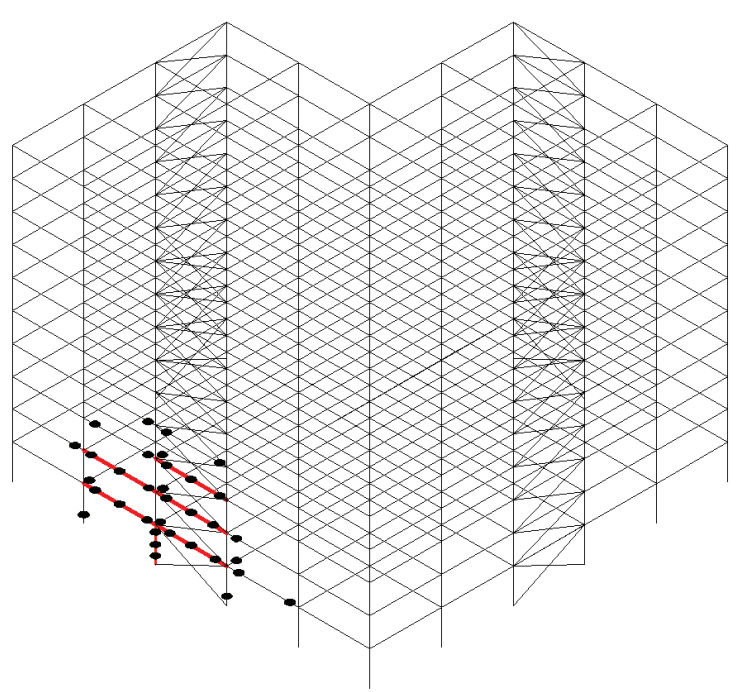

(b) $\mathrm{H}-\mathrm{CBF}$

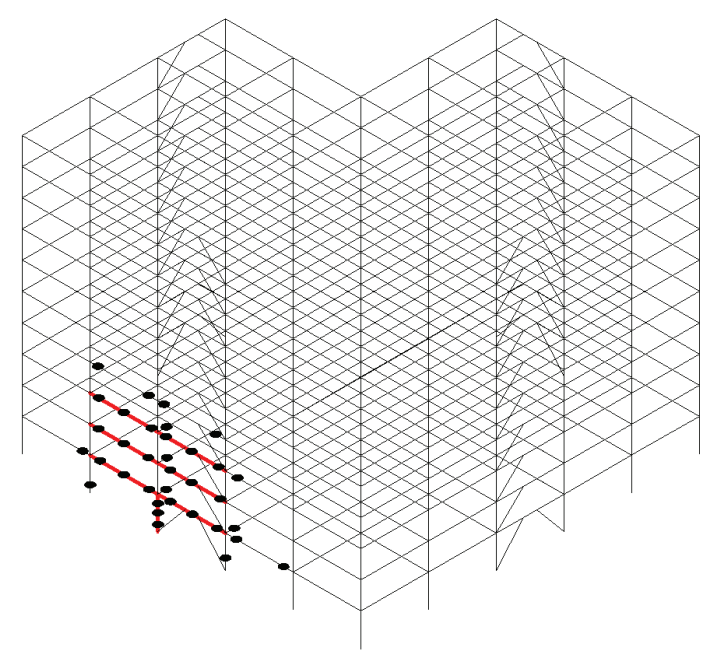

(c) $\mathrm{H}-\mathrm{EBF}$

Fig. 5. Member failure and plastic hinge locations for horizontally irregular MRF, CBF, EBF - Blast Location 1

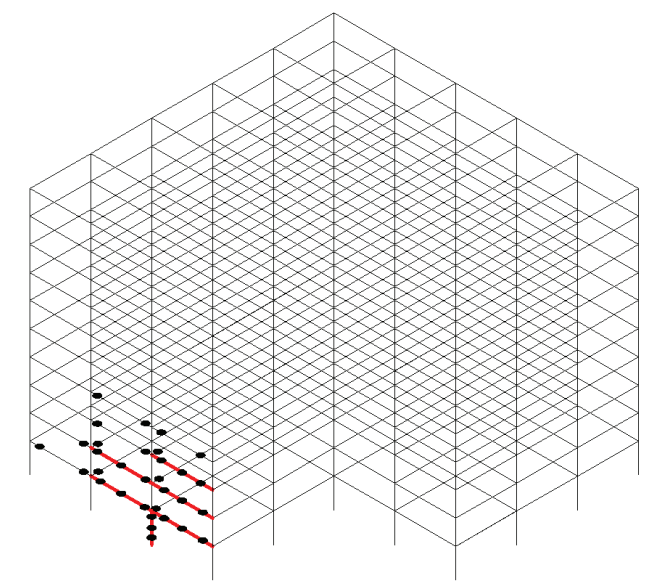

a) H-MRF

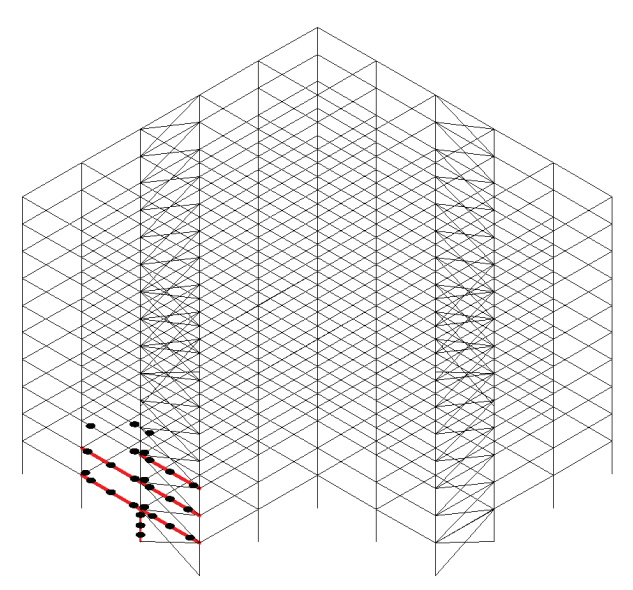

(b) $\mathrm{H}-\mathrm{CBF}$

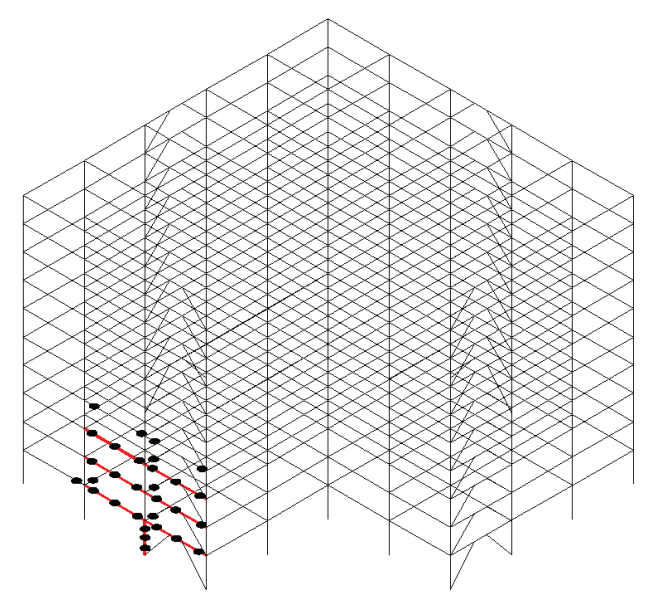

(c) $\mathrm{H}-\mathrm{EBF}$

Fig. 6. Member failure and plastic hinge locations for horizontally irregular MRF, CBF, EBF - Blast Location 2 


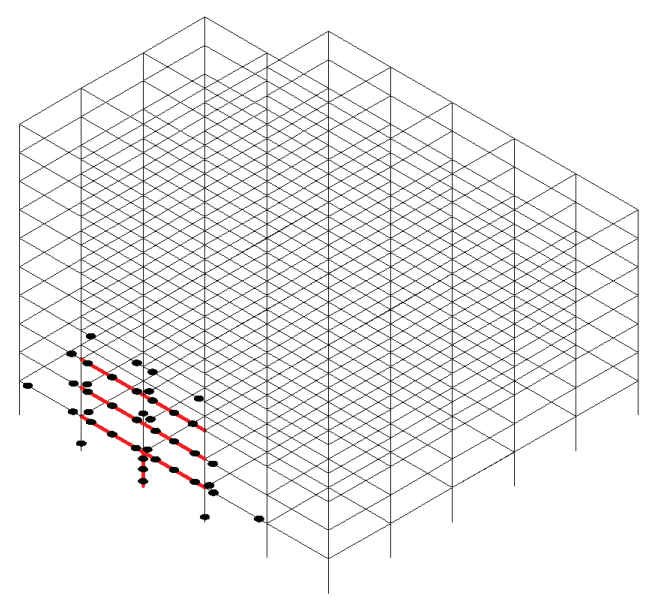

(a) V-MRF

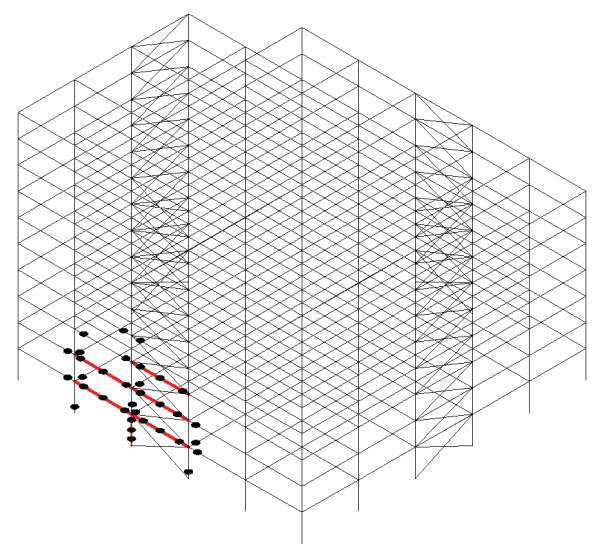

(b) V-CBF

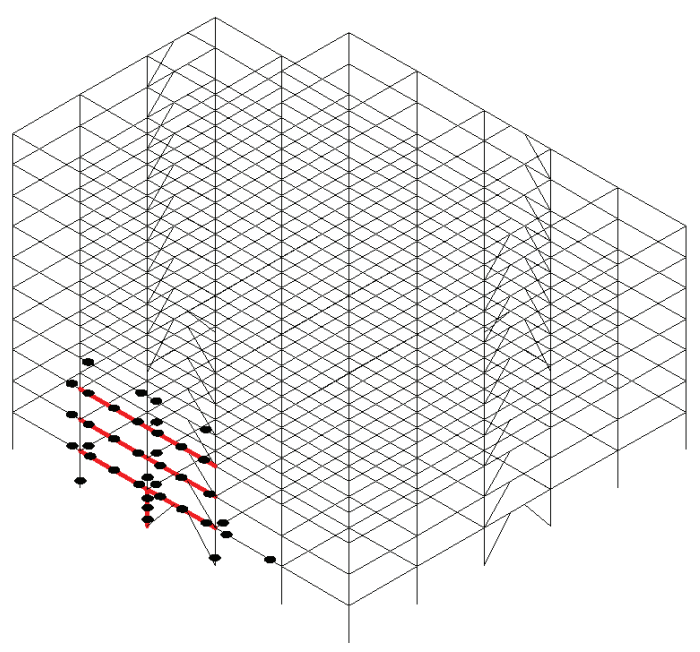

(c) V-EBF

Fig. 7. Member failure and plastic hinge locations for vertically irregular MRF, CBF, EBF - Blast Location 1

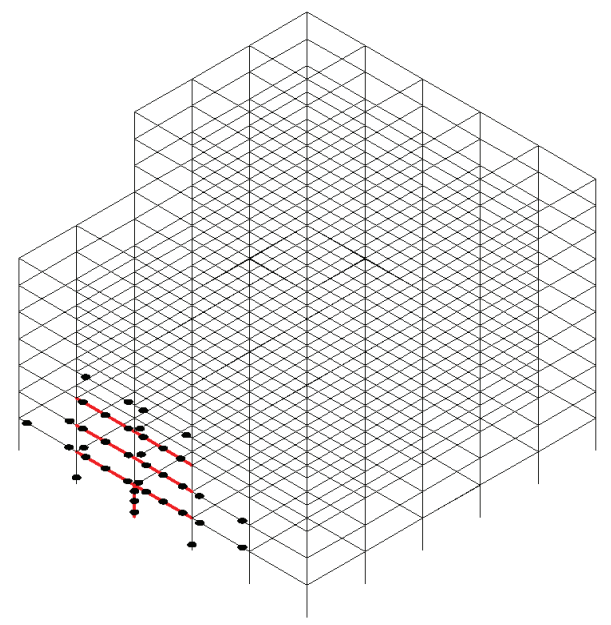

(a) V-MRF

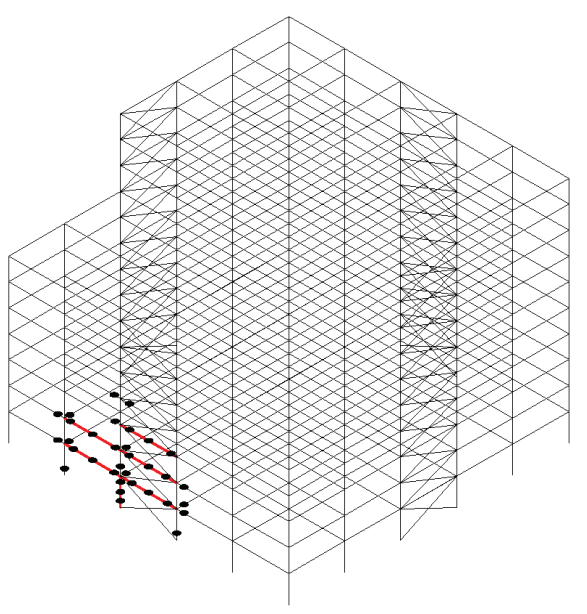

b) $\mathrm{V}-\mathrm{CBF}$

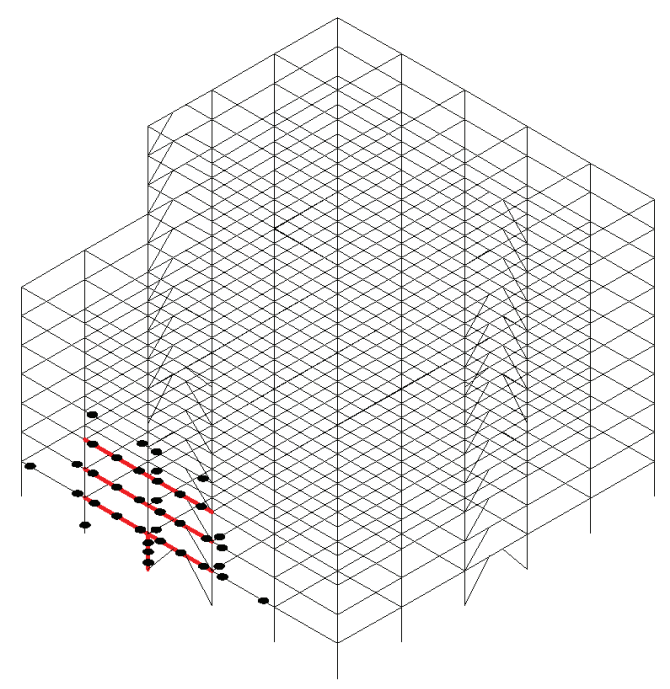

(c) V-EBF

Fig. 8. Member failure and plastic hinge locations for vertically irregular MRF, CBF, EBF - Blast Location 2 
Table 8. Plastic hinge and member failure for irregular MRF, EBF, and CBF

\begin{tabular}{|c|c|c|c|c|c|c|c|c|c|c|c|c|c|c|}
\hline & \multirow[b]{2}{*}{ Structure } & \multicolumn{2}{|c|}{ Member failure } & \multicolumn{11}{|c|}{ Number of plastic hinges } \\
\hline & & Column & Beam & $\begin{array}{c}\text { Story } \\
1\end{array}$ & $\begin{array}{c}\text { Story } \\
2\end{array}$ & $\begin{array}{c}\text { Story } \\
3\end{array}$ & $\begin{array}{c}\text { Story } \\
4\end{array}$ & $\begin{array}{c}\text { Story } \\
5\end{array}$ & $\begin{array}{c}\text { Story } \\
6\end{array}$ & $\begin{array}{c}\text { Story } \\
7\end{array}$ & $\begin{array}{c}\text { Story } \\
8\end{array}$ & $\begin{array}{c}\text { Story } \\
9\end{array}$ & $\begin{array}{c}\text { Story } \\
10\end{array}$ & TOTAL \\
\hline \multirow{6}{*}{ 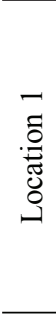 } & H-MRF & 1 & 5 & 18 & 9 & 8 & 4 & 0 & 0 & 0 & 0 & 0 & 0 & 39 \\
\hline & $\mathrm{H}-\mathrm{CBF}$ & 1 & 5 & 16 & 9 & 6 & 3 & 0 & 0 & 0 & 0 & 0 & 0 & 34 \\
\hline & H-EBF & 1 & 6 & 16 & 7 & 8 & 4 & 0 & 0 & 0 & 0 & 0 & 0 & 35 \\
\hline & V-MRF & 1 & 6 & 18 & 10 & 8 & 4 & 0 & 0 & 0 & 0 & 0 & 0 & 40 \\
\hline & $\mathrm{V}-\mathrm{CBF}$ & 1 & 5 & 16 & 11 & 5 & 2 & 0 & 0 & 0 & 0 & 0 & 0 & 34 \\
\hline & V-EBF & 1 & 6 & 17 & 9 & 8 & 4 & 0 & 0 & 0 & 0 & 0 & 0 & 38 \\
\hline \multirow{6}{*}{ 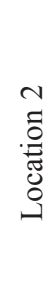 } & H-MRF & 1 & 5 & 13 & 9 & 6 & 4 & 0 & 0 & 0 & 0 & 0 & 0 & 32 \\
\hline & $\mathrm{H}-\mathrm{CBF}$ & 1 & 5 & 11 & 7 & 6 & 2 & 0 & 0 & 0 & 0 & 0 & 0 & 26 \\
\hline & H-EBF & 1 & 6 & 12 & 7 & 7 & 4 & 0 & 0 & 0 & 0 & 0 & 0 & 30 \\
\hline & V-MRF & 1 & 6 & 17 & 10 & 7 & 4 & 0 & 0 & 0 & 0 & 0 & 0 & 38 \\
\hline & $\mathrm{V}-\mathrm{CBF}$ & 1 & 5 & 16 & 11 & 4 & 2 & 0 & 0 & 0 & 0 & 0 & 0 & 33 \\
\hline & V-EBF & 1 & 6 & 16 & 10 & 6 & 4 & 0 & 0 & 0 & 0 & 0 & 0 & 36 \\
\hline
\end{tabular}

that is, six or seven members. For the horizontally irregular structures, the MRF and CBF had 6 member failures and the EBF had 7 member failures. For the vertically irregular structures, however, the CBF experienced the fewest number of failed members with 6 as opposed to 7 for the MRF and the EBF. The plastic hinge analysis resulted in the CBF consistently yielding the fewest number of plastic hinges for both types of irregularity and blast locations. The same results were found for regular structures in the companion paper.

Table 9 provides the maximum roof deflection and acceleration in the direction of the blast for the three framing systems. The CBF yielded the smallest roof deflection and acceleration, followed by the EBF and the MRF. Compared with the MRF, the CBF had 25\% and

Table 9. Maximum roof deflection and acceleration for irregular $\mathrm{MRF}, \mathrm{EBF}$, and $\mathrm{CBF}$

\begin{tabular}{l|c|c|c}
\hline & Structure & $\begin{array}{c}\text { Roof } \\
\text { deflection } \\
\text { (in) }\end{array}$ & $\begin{array}{c}\text { Roof } \\
\text { acceleration (ft/ } \\
\left.\text { sec }^{\wedge} 2\right)\end{array}$ \\
\hline \multirow{5}{*}{ Location 1 } & H-MRF & 1.82 & 96 \\
& H-CBF & 1.37 & 80 \\
& H-EBF & 1.5 & 83 \\
& V-MRF & 1.9 & 106 \\
& V-CBF & 1.46 & 90 \\
& V-EBF & 1.56 & 95 \\
\hline \multirow{5}{*}{ Location 2 } & H-MRF & 1.39 & 43 \\
& H-CBF & 1.17 & 28 \\
& H-EBF & 1.21 & 31 \\
& V-CBF & 1.52 & 25 \\
& V-EBF & 1.23 & 21 \\
\hline
\end{tabular}

$16 \%$ less roof deflection and $17 \%$ and $35 \%$ less roof acceleration for the horizontally irregular structures given blast location 1 and blast location 2, respectively. The CBF had 23\% and 20\% less roof deflection and 15\% and $16 \%$ less roof acceleration for the vertically irregular structures given blast location 1 and blast location 2 , respectively.

\subsection{Effect of irregularity}

The six irregular structures analyzed in this report are compared to the three regular structures presented in Coffield and Adeli (2014).

\section{Blast Location 1}

For the horizontally irregular structures, the number of failed members did not change for the MRF and CBF; however, the EBF experienced two more failed members when compared to regular structures. For the vertically irregular structures, the number of failed members did not change for the $\mathrm{CBF}$, however, the MRF experienced one more failed member and the EBF experienced two more failed members.

In general, for this blast location irregular structures had more plastic hinges than the corresponding regular structures. For the horizontally irregular structures, CBF had two more plastic hinges and EBF had one more plastic hinge compared to the regular structures. For the vertically irregular structures, one more plastic hinge formed in the MRF, two more plastic hinges in the CBF and four more plastic hinges in the EBF when compared to the regular structures.

For all structural types a vertical or horizontal irregularity results in a larger roof deflection in the order of $5-9 \%$. 


\section{Blast Location 2}

The number of failed members for blast location 2 happens to be the same as blast location 1. For the horizontally irregular structures, five fewer plastic hinges formed in the MRF, six fewer formed in the CBF and four fewer formed in the EBF when compared to the regular structures. For the vertically irregular structures, one fewer plastic hinge formed in the MRF, one more plastic hinge in the $\mathrm{CBF}$ and two more plastic hinges formed in the EBF when compared to the regular structures. The number of plastic hinges is consistently fewer for the horizontally irregular structure compared to the regular structures but inconsistent for vertically irregular structure.

For all structural types a vertical or horizontal irregularity results in a smaller roof deflection in the order of $12-17 \%$.

\section{Conclusions}

The effects of structural irregularity on seismically designed steel framing systems subjected to blast loading conditions were investigated. The main conclusions of this study are:

1. A concentrically braced frame provides somewhat of a higher level of resistance to blast loading for irregular structures.

2. Geometric irregularity has an impact on the response of a structure subjected to blast loading. All three structure types performed better when the source of the blast was on the side of the setback or reentrant corner.

The latter conclusion has practical significance in architectural design, placement, and orientation of a highrise building structure in terms of minimizing its potential damage to blast loading.

Other types of structural irregularity such as mass and the stiffness of the structure can influence its blast resistance which can be the subject of future research.

\section{References}

Adeli, H.; Chyou, H. 1986. Plastic analysis of irregular frames on microcomputers, Computers and Structures 23(2): 233-240.

http://dx.doi.org/10.1016/0045-7949(86)90215-4

Adeli, H.; Mabrouk, N. 1986. Optimum plastic design of unbraced frames of irregular configuration, International Journal of Solids and Structures 22(10): 1117-1128. http://dx.doi.org/10.1016/0020-7683(86)90021-1

AISC. 2010. Steel construction manual. $14^{\text {th }}$ ed. American Institute of Steel Construction, Chicago, IL.

ASCE. 2010. Minimum design loads for buildings and other structures - SEI/ASCE Standatd No. 7-10. American Society of Civil Engineers, Reston, VA.

Coffield, A.; Adeli, H. 2014. An investigation of the effectiveness of the framing systems in steel structures subjected to blast loading, Journal of Civil Engineering and Management 20(6): 767-777. http://dx.doi.org/10.3846/13923730.2014.986667

Gutierrez-Soto, M.; Adeli, H. 2014. Optimum tuning parameters of tuned mass dampers for vibration control of irregular highrise building structures, Journal of Civil Engineering and Management 20(5): 609-620. http://dx.doi.org/10.3846/13923730.2014.967287

Jayatilake, I. N.; Dias, W. P. S.; Jayasinghe, M. T. R.; Thambiratnam, D. P. 2010. Response of tall buildings with symmetric setbacks under blast loading, Journal of National Science Foundation of Sri Lanka 38(2): 115-123.

Jiang, X.; Adeli, H. 2008. Dynamic fuzzy wavelet neuroemulator for nonlinear control of irregular highrise building structures, International Journal for Numerical Methods in Engineering 74(7): 1045-1066. http://dx.doi.org/10.1002/nme.2195

Kim, H.; Adeli, H. 2005. Hybrid control of irregular steel highrise building structures under seismic excitations, International Journal for Numerical Methods in Engineering 63(12): 1757-1774. http://dx.doi.org/10.1002/nme.1336

Nigdeli, S. M.; Boduroğlu, M. H. 2013. Active tendon control of torsionally irregular structures under near-fault ground motion excitation, Computer-Aided Civil and Infrastructure Engineering 28(9): 718-736. http://dx.doi.org/10.1111/mice.12046

Young, K.; Adeli, A. 2014a. Fundamental period of irregular moment resisting steel frames, The Structural Design of Tall and Special Buildings 23(15): 1141-1157. http://dx.doi.org/10.1002/tal.1112

Young, K.; Adeli, A. 2014b. Fundamental period of irregular concentrically braced steel frame structures, The Structural Design of Tall and Special Buildings 23(16): 12111224. http://dx.doi.org/10.1002/tal.1136

Amy COFFIELD. She graduated from The Ohio State University in 2010 with a Bachelor's of Science Degree in Civil Engineering. She received her Master's of Science Degree in Civil Engineering from The Ohio State University in 2013. Since 2012 she has worked as a Structural Engineer at River Consulting in Columbus, Ohio.

Hojjat ADELI. He is Professor of Civil, Environmental, and Geodetic Engineering at The Ohio State University. He has authored of over 500 publications including 15 books since he received his PhD from Stanford University in 1976 at the age of $26 . \mathrm{He}$ is the recipient of numerous awards and honors including The Ohio State University's highest research honor, the Distinguished Scholar Award "in recognition of extraordinary accomplishment in research and scholarship". He is the quadruple-winner of the OSU College of Engineering Lumley Outstanding Research Award. He received the ASCE Construction Management Award in 2006. In 2007 he received the Peter L. and Clara M. Scott Award for Excellence in Engineering Education for sustained, exceptional, and multi-faceted contributions to numerous fields including computer-aided engineering, knowledge engineering, computational intelligence, large-scale design optimization, and smart structures with worldwide impact, and Charles E. MacQuigg Outstanding Teaching Award from The Ohio State University College of Engineering. He is also the 2014 recipient of Eduardo Renato Caianiello Award from the Italian Society of Neural Networks (SIREN), and a Special Medal from the Polish Neural Network Society. In 1998 he was awarded a United States patent for his neural dynamics model for design automation and optimization (jointly with a former $\mathrm{PhD}$ student). He is a Fellow of AAAS, IEEE, and the American Neurological Association. 